International Research Journal of Management, IT \& Social Sciences
Available online at https://sloap.org/journals/index.php/irjmis/
Vol. 6 No. 3, May 2019, pages: 83 93
ISSN: 2395-7492
https://doi.org/10.21744/irjmis.v6n3.635

\title{
Effect of Self-efficacy, Competence and Compensation in Performance of Financial Manager on Motivation as Moderation
}

\author{
Kadek Dwiyani Ciptana Putri ${ }^{\text {a }}$ \\ Maria Mediatrix Ratna Sari ${ }^{b}$ \\ I Wayan Ramantha ${ }^{c}$ \\ I Gusti Ayu Nyoman Budiasih ${ }^{\mathrm{d}}$
}

\section{Article history:}

Received: 27 December 2018

Accepted: 31 March 2019

Published: 16 May 2019

\begin{abstract}
This study aims to examine the effect of self-efficacy, competence, and compensation on the performance of financial management employees with motivation as moderating. The population in this study were all financial management employees at Udayana University in 2019. The study sample was determined by the nonprobability sampling method which obtained a total sample of 92 people. This study uses primary data and secondary data. The data analysis technique used in the study was multiple linear regression analysis and moderated regression analysis. The results showed that the variables of self-efficacy, competence, and compensation had a positive effect on the performance of financial management employees. Motivation does not moderate the effect of self-efficacy and competence on the performance of financial management employees. Motivation strengthens the effect of compensation on the performance of financial management employees.
\end{abstract}

2395-7492@ Copyright 2019. The Author. This is an open-access article under the CC BY-SA license (https://creativecommons.org/licenses/by-sa/4.0/) All rights reserved.

\section{Author correspondence:}

Kadek Dwiyani Ciptana Putri,

Faculty of Economic \& Business, Udayana University, Bali, Indonesia.

Email address: ciptanauti@gmail.com

\section{Introduction}

Competence is a combination of knowledge and skills in the management circle, which shows stable characteristics and is related to one's maximum physical and mental abilities. Competence relates to what someone does at work at various levels and standards of each level, which identifies the characteristics, knowledge, and skills needed by employees to carry out their duties and responsibilities effectively so as to achieve professional quality standards at

\footnotetext{
${ }^{a}$ Faculty of Economic \& Business, Udayana University, Bali, Indonesia

${ }^{\mathrm{b}}$ Faculty of Economic \& Business, Udayana University, Bali, Indonesia

${ }^{\mathrm{c}}$ Faculty of Economic \& Business, Udayana University, Bali, Indonesia

${ }^{\mathrm{d}}$ Faculty of Economic \& Business, Udayana University, Bali, Indonesia
} 
work. The standard covers all aspects of performance management records, specific skills, and knowledge, attitudes, communication, applications, and development.

In the public sector, performance emphasizes and prioritizes the final results that are truly felt by the community. Therefore, organizations need employees who are truly capable of carrying out their duties effectively, efficiently, efficiently, with high quality and responsibility, so that they can work with optimal results. The ability needed to carry out work is an individual characteristic that underlies employee performance. This ability is not just attitude and behavior, but knowledge and skills, because the ability is a competency that is very necessary to work so that the results achieved can contribute to performance, both individual performance and performance in the organization. Competence concerns the ability of individuals to carry out their duties or determine decisions according to their roles, knowledge, skills and productive attitudes (Pratiwi et al., 2019; Bire et al., 2019).

Managing human resources based on competence is believed to be able to support the organization to achieve its goals. Competence is usually used as a basis for each entity in selecting people, managing performance, carrying out training and development and determining compensation. People who have high competence are expected to have good performance so that every employee is required to improve their competence in an effort to improve organizational performance. Good quality performance in managing the organization is very necessary so that employees who are competent in their fields are needed. The competencies possessed by an employee are very important as the basis of his ability to carry out tasks and jobs that are his responsibility, with the competency the more types of work performed by employees, the more extensive and extensive work experience, and can improve performance.

Based on previous research, many studies on competency have been carried out, namely Suwardji et al., (2012) and Adiputra (2011), where competence affects performance. However, other researchers mentioned differently, Syachbrani (2014) and Sofyani \& Akbar (2014), stated that competence does not affect the performance of government agencies. The results of the study conducted by Sampe (2014), which examined the effect of competency on the performance of employees of Hasanuddin University UPT library. The results of the study showed that simultaneous competence had a significant effect on the performance of library UPT employees.

In addition to high competence, it is important to achieve optimal performance, one of which can be achieved through self-efficacy. Self-efficacy is a person's belief about his opportunity to succeed in achieving tasks and achieving results (Prasetya, 2013). Self-efficacy is needed in developing employee performance because the existence of self-efficacy in the individual will lead to confidence in the ability of him to complete the work given by his boss in a timely manner. High self-efficacy individuals will achieve a better performance because the individual has strong motivation, clear goals, stable emotions and the ability to deliver performance on activities or behavior successfully. Someone who has high self-efficacy they are able to do something to change the events around him, while someone with low self-efficacy considers himself basically unable to do everything around him. In difficult situations, people who have low self-efficacy tend to give up easily, while people who have high self-efficacy will try harder to overcome the challenges. The good performance of an employee will make self-efficacy even higher (Sapariyah, 2011).

Several studies on self-efficacy on performance have also been carried out by several researchers and showed different results. Research conducted by Purnomo \& Lestari (2010), shows the results that self-efficacy has a significant positive effect on the performance of SMEs. Research with different results was carried out by Gunawan \& Sutanto (2013) and Prasetya et al., (2013), showed the results that self-efficacy had no effect on employee performance and individual performance. Research conducted by Cherian \& Jacob (2013), shows the results that selfefficacy on individual performance in the workplace will determine its performance and motivation.

Not only employees' skills, but competencies and self-efficacy factors must also be developed by organizations to improve employee performance. However, organizations must also pay attention to the compensation factor as a motive for employees to work. Providing compensation for employees is an obligation for organizations that must be fulfilled on time, carried out fairly and based on work results. Compensation is everything that employees receive as a reward for their work. According to Simamora (1997), compensation consists of Financial Compensation (principal payments, performance payments, incentive payments, paid fees, protection programs, non-working hours, facilities) and Financial Compensation (work and work environment).

Giving compensation from the organization is one of the important factors that influence the election to work in an organization. Provision of appropriate compensation for the desires of employees and organizational capabilities will create healthy cooperative relationships for the advancement of organizational performance. In addition, compensation that is in accordance with the wishes of employees for their work can spur employee morale to work better from time to time, thus providing a positive influence on improving employee work outcomes (Yanti et al., 2019; Gorda et al., 2018). Satisfaction with the amount of compensation is the main element in creating job satisfaction. In addition,

Putri, K. D. C., Sari, M. M. R., Ramantha, I. W., \& Budiasih, I. G. A. N. (2019). Effect of self-efficacy, competence and compensation in performance of financial manager on motivation as moderation. International Research Journal of Management, IT and Social Sciences, 6(3), 83-93. https://doi.org/10.21744/irjmis.v6n3.635 
compensation satisfaction also plays a role in forming an employee's attitude to work (Simamora, 1997). There is a kind of return of hope between the compensation organization and the employee who receives it, the purpose of a working worker is to obtain compensation and the organization expects employees to provide the best performance for their organization (Sutrisno, 2011).

\section{Literature Review}

\section{The Effect of Self Efficacy on the Performance of Financial Management Employees}

Someone who has high self-efficacy will be able to do something to change the events around him, while someone with low self-efficacy considers himself basically unable to do everything around him. In difficult situations, people who have low self-efficacy tend to give up easily, while people who have high self-efficacy will try harder to overcome the challenges. The higher a person's self-efficacy will make the performance of an employee better (Sapariyah, 2011). Based on the description, the formulation of the $\mathrm{H} 1$ hypothesis is as follows.

H1: Self-efficacy has a positive effect on the performance of financial management employees.

\section{The effect of Competence \on the Performance of Financial Management Employees}

Managing human resources based on competence is believed to be able to support the organization to achieve its goals. Competence is usually used as a basis for each entity in selecting people, managing performance, carrying out training and development and determining compensation. People who have high competence are expected to have good performance so that every employee is required to improve their competence in an effort to improve organizational performance. Based on the description, the formulation of the $\mathrm{H} 2$ hypothesis is as follows.

$\mathrm{H} 2$ : Competence has a positive effect on the performance of financial management employees.

\section{The Effect of Compensation on the Performance of Financial Management Employees}

Sutrisno (2011) and Firmandari (2014), research states that compensation has an effect on performance. Organizations must pay attention to the factor of giving compensation as one of the motives for employees to work. Providing compensation for employees is an obligation for organizations that must be fulfilled on time, carried out fairly and based on work results. Compensation is everything that is received by employees as a reward for the work of the employee. The satisfaction of compensation also plays a role in shaping the attitude of an employee at work (Simamora, 1997). Based on the description, the formulation of the H3 hypothesis is as follows.

H3: Compensation has a positive effect on the performance of financial management employees.

The Effect of Self Efficacy on Financial Management Employee Performance with Motivation as Moderating

The relationship between motivation on the effect of self-efficacy on performance can be explained in expectation theory. Not all workers have performance that matches the expectations of the organization. This can occur because of the low self-efficacy that is owned by employees. Research by Purnomo \& Lestari (2010); Sebayang \& Sembiring (2017), states that self-efficacy has an effect on performance. Narsim (2008); Irmayati et al., (2015); Zhahzadi et al., (2014); Syardianto et al., (2014); and Widnyana (2015), found that motivation influences employee performance and motivation contribute to improving performance. Therefore, the existence of motivation is very necessary in order to encourage employees to be more enthusiastic in doing their jobs. Employees with low motivation will often display discomfort and displeasure with their work so that employee performance is poor and work performance is not visible. Based on the description, the formulation of the hypothesis is as follows.

H4: Motivation is able to strengthen the effect of self-efficacy on the performance of financial management employees.

\section{The Effect of Competence on Financial Management Employee Performance with Motivation as Moderating}

The relationship between motivation on the influence of competence on performance can be explained in expectation theory. Every employee doing an activity in an organization will grow awareness so that it is motivated and will function as a form of attitudes and responsibilities as employees. Research by Suwardji et al., (2012); Adiputra (2011) and Sampe (2014), state that competence influences performance. The role of motivation is very important for employees and will have an impact on the survival of the organization. This shows that work motivation must exist in each employee in order to improve employee performance. According to Burney in Oluseyi \& Ayo (2009), states that the level of performance is not only based on actual abilities but also based on the level of motivation shown. Employees who have high work competencies but are not accompanied by high work motivation so that their work is not good and vice versa. It should be noted that there are employees who have low workability but have genuine work 
motivation, so the work can be done well, with the motivation of an employee who will feel an urge to complete work towards achieving organizational effectiveness (Sarifuddin, 2016). Based on the description, the formulation of the hypothesis is as follows.

H5: Motivation can strengthen the influence of competency on the performance of financial management employees.

The Effect of Compensation on Employee Performance of Financial Managers with Motivation as Moderating

The relationship between motivation on the effect of compensation on performance can be explained in expectation theory. Employees who are motivated by the amount of salary and benefits will work earnestly and energetically, eager to do the tasks given by the company to get a better career. Sutrisno (2011) and Firmandari (2014), research states that compensation has an effect on performance. Giving salaries and benefits that are considered appropriate, will affect the company's performance. With the work motivation of employees, both in the form of salary, allowances, and bonuses, it will further improve employee performance results. Based on the description, the formulation of the hypothesis is as follows.

H6: Motivation can strengthen the effect of compensation on the performance of financial management employees.

\section{Materials and Methods}

In this study using nonprobability sampling method with a saturated sampling technique in which all members of the population are used as samples. Respondents chosen in this study were civil servants of financial management at Udayana University, namely Commitment Making Officials (PPK), Officials Signing Paying Orders (PPSPM), Head of Financial Subdivision (Head of Subdivision of Finance), Assistant Treasurer of Expenditure (BPP) and Expenditure Treasurer Members Assistant numbering 92 people.

The distribution of the questionnaire was carried out directly by the researcher to the respondents, namely the civil servants of Udayana University to obtain data on the variables of self-efficacy, competence, compensation, motivation, and performance of the financial management staff of Udayana University. The questionnaire collected by the author will be examined for completeness and only a complete questionnaire will be used as the data source. The next stage will be hypothesis testing using moderated regression analysis (MRA).

\section{Results and Discussions}

The regression model in this study uses multiple linear regression analysis, the following in Table 1 are the results of multiple linear regression analysis.

Table 1

Multiple regression analysis testing result

\begin{tabular}{lll}
\hline & Beta Unstandardized & Sig. \\
\hline Self-Efficacy & 0,276 & 0,000 \\
Competence & 0,233 & 0,007 \\
Compensation & 0,151 & 0,010 \\
Motivation & 0,140 & 0,026 \\
Constant & 76,781 & \\
Sig. Uji F. & 0,000 & \\
Adjusted $\boldsymbol{R}$ Square & 0,951 & \\
\hline
\end{tabular}

Primer Data, 2019

The results of the $\mathrm{F}$ test ( $\mathrm{F}$ test) indicate that the significance value of 0,000 is smaller than the alpha value of 0.05 , meaning that the model used in this study is feasible. This result gives the meaning that the four independent variables are able to predict or explain performance phenomena in financial management employees. In the Table, it can be seen that the adjusted amount of $\mathrm{R} 2$ is 0.951 . This means that performance variations can be explained by variations in selfefficacy, competence, compensation, and motivation of 95.1 percent, while the remaining 4.9 percent is explained by other factors.

Putri, K. D. C., Sari, M. M. R., Ramantha, I. W., \& Budiasih, I. G. A. N. (2019). Effect of self-efficacy, competence and compensation in performance of financial manager on motivation as moderation. International Research Journal of Management, IT and Social Sciences, 6(3), 83-93. https://doi.org/10.21744/irjmis.v6n3.635 
Moderate regression analysis is used to determine the ability of the moderating variable to moderate the influence of independent variables on the dependent variable. The results of the moderation regression analysis are shown in Table 2.

Table 2

Multiple regression analysis testing result

\begin{tabular}{lll}
\hline & Beta Unstandardized & Sig. \\
\hline Self-Efficacy & 0,710 & 0,011 \\
Competence & 0,069 & 0,816 \\
Compensation & $-0,158$ & 0,304 \\
Motivation & 0,147 & 0,412 \\
SE.M & $-0,036$ & 0,115 \\
KM.M & 0,013 & 0,569 \\
KP.M & 0,028 & 0,041 \\
Constant & 76,009 & \\
Sig. Uji F. & 0,000 & \\
Adjusted $R$ Square & 0,953 & \\
\hline
\end{tabular}

Primary Data, 2019

First Hypothesis (H1)

The calculation results shown in Table 1 are known that the value of $\beta 1$ for the self-efficacy variable is 0.276 with a significance level of 0.000 smaller than 0.05 . This shows that the self-efficacy variable has a positive effect on performance. The first hypothesis (H1) which states self-efficacy has a positive effect on acceptable performance.

The results of this analysis are consistent with the results of research conducted by Purnomo \& Lestari (2010); Sapariyah (2011), and Sebayang \& Sembiring (2017), which state that self-efficacy affects performance. High selfefficacy will achieve a better performance because the individual has a strong motivation, clear goals, stable emotions and abilities to successfully perform activities on behavior. This is supported by expectations theory which states that our tendency to act in a certain way depends on the strength of our expectations regarding the results given and their interests. Likewise, the financial management staff of Udayana University, employees with high self-efficacy, are sure to work better. This is because employees always feel able to complete each job and they are satisfied with the results of their work. So that an employee who has high self-efficacy will produce a good performance.

\section{Second Hypothesis (H2)}

The calculation results shown in Table 1 are known that the value of $\beta 2$ for the competency variable is 0.233 with a significance level of 0.007 smaller than 0.05 . This shows that the competency variable has a positive effect on performance. The second hypothesis (H2) which states competence has a positive effect on acceptable performance. The results of this analysis are consistent with the results of research conducted by Suwardji et al., (2012); Adiputra (2011) and Sampe (2014), stating that competence influences performance. Employees with adequate competence will be able to work more effectively and efficiently. This is supported by expectations theory which states that our tendency to act in a certain way depends on the strength of our expectations regarding the results given and their interests. The performance of an employee will be good, if the employee has high expertise, willingness to work, there are rewards/wages that are reasonable and have hope for the future. To realize this, the organization will strive in various ways, one of which is by recruiting employees with adequate competencies.

\section{Third Hypothesis (H3)}

The calculation results shown in Table 1 are known that the value of $\beta 3$ for the compensation variable is 0.151 with a significance level of 0.010 smaller than 0.05 . This shows that the compensation variable has a positive effect on performance. The third hypothesis (H3) which states compensation has a positive effect on acceptable performance.

The results of this analysis are consistent with the results of research conducted by Sutrisno (2011) and Firmandari (2014), stating that compensation affects performance. Organizations must pay attention to the factor of giving compensation as one of the motives for employees to work. This is supported by expectations theory which states that our tendency to act in a certain way depends on the strength of our expectations regarding the results given and their interests. In more practical terms, workers will lead to good performance appraisals that will lead to organizational 
rewards, for example increasing intrinsic salaries or rewards, and that rewards will satisfy the personal goals of the workers.

\section{Fourth Hypothesis (H4)}

The calculation results shown in Table 2 show that the value of $\beta 4$ for the interaction variable between self-efficacy and motivation is -0.036 with a significance level of 0.115 greater than 0.05 . This shows that motivation is not able to moderate the effect of self-efficacy with performance variables. The fourth hypothesis (H4) which states motivation reinforces the effect of self-efficacy on performance is rejected.

Employees with low or high motivation when the employee's self-efficacy in not being able to survive in a low team will not produce good performance or the resulting performance will be bad. These results are not consistent with the Narsim (2008); Irmayati et al., (2015); Zhahzadi et al., (2014); Syardianto et al., (2014); and Widnyana (2015), which stated that motivation influences employee performance and motivation contribute to improving performance.

\section{Fifth Hypothesis (H5)}

The calculation results shown in Table 2 are known that the value of $B 5$ for the interaction variable between competence and motivation is 0.013 with a significance level of 0.569 greater than 0.05 . This shows that motivation is not able to moderate the influence of competence on performance. The fifth hypothesis (H5) which states motivation strengthens the influence of competence on performance is rejected.

The results of this test are supported by Pratiningsih (2015), the study which states that the motivation variable does not moderate the influence of the competency variable on employee performance. This means that the motivation in this study is better to be an independent variable rather than a moderating variable. This is in accordance with the statement from Mahmudi (2005), that to give birth to performance is not easy because obtaining performance (performance) is strongly influenced by factors that affect performance, among others, are personal factors that include knowledge, skills (skills), ability, confidence, motivation, and commitment that each individual has.

\section{Sixth Hypothesis (H6)}

The calculation results shown in Table 2 are known that the value of $B 6$ for the interaction variable between compensation and motivation is 0.028 with a significance level of 0.041 smaller than 0.05 . This shows that motivation can strengthen the effect of compensation on performance. The sixth hypothesis (H6) which states motivation reinforces the effect of compensation on acceptable performance.

The results of this test are consistent with the research of Sutrisno (2011) and Firmandari (2014), stating that compensation affects performance. Giving salaries and benefits that are considered appropriate, will affect the company's performance. This is supported by expectations theory which states that our tendency to act in a certain way depends on the strength of our expectations regarding the results given and their interests. With the work motivation of employees, both in the form of salary, allowances, and bonuses, it will further improve employee performance results. The relationship between motivation on the effect of compensation on performance can be explained in expectation theory. Employees work hard in the hope of getting appropriate compensation or even more. Employees who are given more compensation will be motivated to produce good or increased performance.

\section{Conclusion}

This study uses respondents from the financial management staff of Udayana University, which is a Public Service Agency (BLU). Future research can use this research as one of the references on similar topics on the performance of financial management employees in other Public Service Agencies and Regional Public Service Agencies. Based on the respondents' average score, employees have not been able to work together in teams and provide good ideas to improve performance success so employees need to be given more training to be more creative, competitive and able to work in teamwork.

Conflict of interest statement and funding sources

The authors declared that they have no competing interest. The study was financed by personal funding.

Putri, K. D. C., Sari, M. M. R., Ramantha, I. W., \& Budiasih, I. G. A. N. (2019). Effect of self-efficacy, competence and compensation in performance of financial manager on motivation as moderation. International Research Journal of Management, IT and Social Sciences, 6(3), 83-93. https://doi.org/10.21744/irjmis.v6n3.635 
Statement of authorship

The authors have a responsibility for the conception and design of the study. The authors have approved the final article.

Acknowledgments

The authors would like to acknowledge the editor of IRJMIS for their support, valuable time, and advice in completing the present article. 


\section{References}

Adiputra, I. M. P. (2011). Hubungan Kompetensi dengan Kinerja Pemeriksa Pajak pada Kantor Pelayanan Pajak Pratama di Badung Selatan. JINAH (Jurnal Ilmiah Akuntansi dan Humanika), 1(1).

Bire, A. R., Sauw, H. M., \& Maria, -. (2019). The effect of financial literacy towards financial inclusion through financial training. International Journal of Social Sciences and Humanities, 3(1), 186-192. https://doi.org/10.29332/ijssh.v3n1.280

Cherian, J., \& Jacob, J. (2013). Impact of self efficacy on motivation and performance of employees.

Firmandari, N. (2014). Pengaruh Kompensasi Terhadap Kinerja Karyawan Dengan Motivasi Kerja Sebagai Variabel Moderasi (Studi Pada Bank Syariah Mandiri Kantor Cabang Yogyakarta). Ekbisi, 9(1).

Gorda, A. O. S., Romayanti, K. N., \& Anggreswari, N. P. Y. (2018). Social capital, spiritual capital, human capital, and financial capital in the management of child welfare institutions. International Journal of Social Sciences and Humanities, 2(3), 12-20. https://doi.org/10.29332/ijssh.v2n3.183

Gunawan, K. J. (2013). Pengaruh Budaya Organisasional terhadap Kinerja Karyawan melalui Self Efficacy dan Temperamen di PT. Nutrifood Surabaya. Agora, 1(1), 47-57.

Irmayanti, S. (2016). Pembelajaran dengan menggunakan system web blog untuk meningkatkan motivasi belajar siswa jurusan akuntansi di SMK YPKK 2 Sleman tahun 2015/2016. Fakultas sains dan teknologi UIN Yogyakarta.

Iskandar, D. Narsim.(2015). Penelitian Tindakan Kelas dan Publikasinya.

Mahmudi, R., \& Rezaee-Bazzaz, A. (2005). Superplastic indentation creep of $\mathrm{Sn}-\mathrm{Pb}-\mathrm{Sb}$ peritectic. Materials Letters, 59(13), 1705-1708. https://doi.org/10.1016/j.matlet.2005.01.054

Oluseyi, S., \& Ayo, H. T. (2009). Influence of work motivation, leadership effectiveness and time management on employees' performance in some selected industries in Ibadan, Oyo State, Nigeria. European Journal of Economics, Finance and Administrative Sciences, 16(1), 7-16.

Prasetya, V., Handayani, D., \& Purbandari, T. (2013). Peran Kepuasan Kerja, self esteem, self efficacy terhadap Kinerja Individual. JRMA| Jurnal Riset Manajemen dan Akuntansi, 1(1), 59-69.

Pratiningsih, I. (2015). Perancangan Dashboard untuk Sistem Informasi Data MTTI (Main Time to Instalation) Divisi Infratel PT. Telkom Indonesia (Doctoral dissertation, Universitas Kristen Maranatha).

Pratiwi, I. Y., Ratnadi, N. M. D., Suprasto, H. B., \& Sujana, I. K. (2019). The effect of role conflict, role ambiguity, and role overload in burnout government internal supervisors with tri hita karana culture as moderation. International Research Journal of Management, IT and Social Sciences, 6(3), 61-69. https://doi.org/10.21744/irjmis.v6n3.630

Purnomo, R., \& Lestari, S. (2010). Pengaruh kepribadian, self-efficacy, dan locus of control terhadap persepsi kinerja usaha skala kecil dan menengah. Jurnal Bisnis dan Ekonomi, 17(2).

Sampe, M.S. (2014). Pengaruh Kompetensi terhadap Kinerja Pustakawan Universitas Hasanuddin. Tesis Magister Program Pascasarjana Universitas Muslim Indonesia. Makassar.

Sapariyah, R. A. (2011). Pengaruh self esteem, self efficacy and locos of control terhadap kinerja karyawan dalam persfektif balance scorecard pada perum pegadaian boyolali. ProBank, 1(7).

Sarifuddin, S. (2016). Pengaruh Kompetensi Terhadap Kinerja Pegawai Dengan Motivasi Kerja Sebagai Variabel Intervening Pada Badan Pusat Statistik Provinsi Sulawesi Barat (Doctoral dissertation, Universitas Terbuka).

Sebayang, F., \& Sembiring, H. (2017). Synthesis of CMC from palm midrib cellulose as stabilizer and thickening agent in food. Oriental Journal of Chemistry, 33(1), 519.

Simamora, H. (1997). Manajemen Sumber Daya Manusia, Yogyakarta. Bagian Penerbitan STIE.

Sofyani, H. (2014). Pengaruh Faktor Teknis, Organisasional Dan Karakteristik Individu Terhadap Implementasi Sistem Pengukuran Kinerja (Studi Empiris Di Pemda Lingkup Daerah Istimewa Yogyakarta) (Doctoral dissertation, Universitas Gadjah Mada).

Sutrisno, A., \& Lee, T. J. (2011). Service reliability assessment using failure mode and effect analysis (FMEA): survey and opportunity roadmap. International journal of engineering, science and technology, 3(7), 25-38.

Suwardji, E., Hasbullah, R., \& Albatross, E. (2012). Hubungan Kompetensi dan Disiplin Kerja Terhadap Kinerja Tenaga Kependidikan Univeritas Singaperbangsa Karawan. Jurnal Manajemen, 10(1), 955.

Syachbrani, W. (2014). Pengaruh Faktor-Faktor Teknis dan Keorganisasian terhadap Pengembangan Sistem Pengukuran Kinerja Pemerintah Pusat (Studi Empiris pada Direktorat Jenderal Anggaran, Kementerian Keuangan Republik Indonesia) (Doctoral dissertation, Universitas Gadjah Mada).

Syardianto, D. Irawan. 2014. Pengaruh Kemampuan Kerja dan Motivasi Kerja Terhadap Kinerja Pegawai Pada Dinas Perhubungan Komunikasi dan Informatika Kabupaten Kutai Timur. Jurnal Administrative Reform, 885-897.

Putri, K. D. C., Sari, M. M. R., Ramantha, I. W., \& Budiasih, I. G. A. N. (2019). Effect of self-efficacy, competence and compensation in performance of financial manager on motivation as moderation. International Research Journal of Management, IT and Social Sciences, 6(3), 83-93. https://doi.org/10.21744/irjmis.v6n3.635 
Widnyana, I. M., \& Piarsa, I. N. (2015). Aplikasi Sistem Informasi Geografis Bengkel di Kota Denpasar Berbasis Android. Jurnal Ilmiah Merpati (Menara Penelitian Akademika Teknologi Informasi).

Yanti, N. M. Y. W. A., \& Dwirandra, A. (2019). The effect of profitability in income smoothing practice with good corporate governance and dividend of payout ratio as a moderation variable. International Research Journal of Management, IT and Social Sciences, 6(2), 12-21. https://doi.org/10.21744/irjmis.v6n2.601 


\section{Biography of Author}

\begin{tabular}{|l|l|}
\hline Kadek Dwiyani Ciptana Putri was born in Denpasar. She finished her study at Udayana \\
University. Currently as an internal auditor at Udayana University. She interested in audit \\
and accounting field. \\
Email: ciptanauti@gmail.com
\end{tabular}

Putri, K. D. C., Sari, M. M. R., Ramantha, I. W., \& Budiasih, I. G. A. N. (2019). Effect of self-efficacy, competence and compensation in performance of financial manager on motivation as moderation. International Research Journal of Management, IT and Social Sciences, 6(3), 83-93. https://doi.org/10.21744/irjmis.v6n3.635 